\title{
MEASURING THE DEGREE OF STUDENTS' SATISFACTION WITH THE VIRTUAL DESIGN STUDIOS IN LIGHT OF THE SPREAD OF THE COVID-19
}

\author{
Eman Nabih Mutlaq Shaqour \\ Architecture Engineering Department, Faculty of Engineering, Nahda University, Benisuef \\ city, Egypt. E-mail: eman.shaqoor@nub.edu.eg. \\ Fidaa Mohammed Barakat Dwiek \\ $\mathrm{Ph} . \mathrm{D}$ in Education (Curricula and teaching Methods)- of Mathematics), Ain Shams university, \\ El-Khalel, Palestine \\ fedadweik@yahoo.com
}

\begin{abstract}
The aim of this research is to identify the degree of the Architecture Engineering Department students' satisfaction with the virtual design studios at NUB within the elearning program in light of the spread of the Corona pandemic. The research sample consisted of (59) students, who were intentionally chosen. The descriptive and analytical approach are used based on the questionnaire. The results showed that the degree of student satisfaction with the virtual design studios was high. In addition, there are students' satisfaction degree did not affect due to variables (gender, previous knowledge of elearning, devices used to attend electronic lectures, type of connection to the Internet, methods of communication with teachers, and programs used in virtual design studios, and the programs used in the tasks assigned to the student), but it was affected with the academic level, as well as the level of computer use, which is positive. The research concluded that the highest degree of students' satisfaction in terms of explaining the material electronically is the ability to save the modifications that have been discussed.
\end{abstract}

\section{KEYWORDS: Virtual Architectural Design Studios, Satisfaction, E-Learning, Corona Pandemic.}

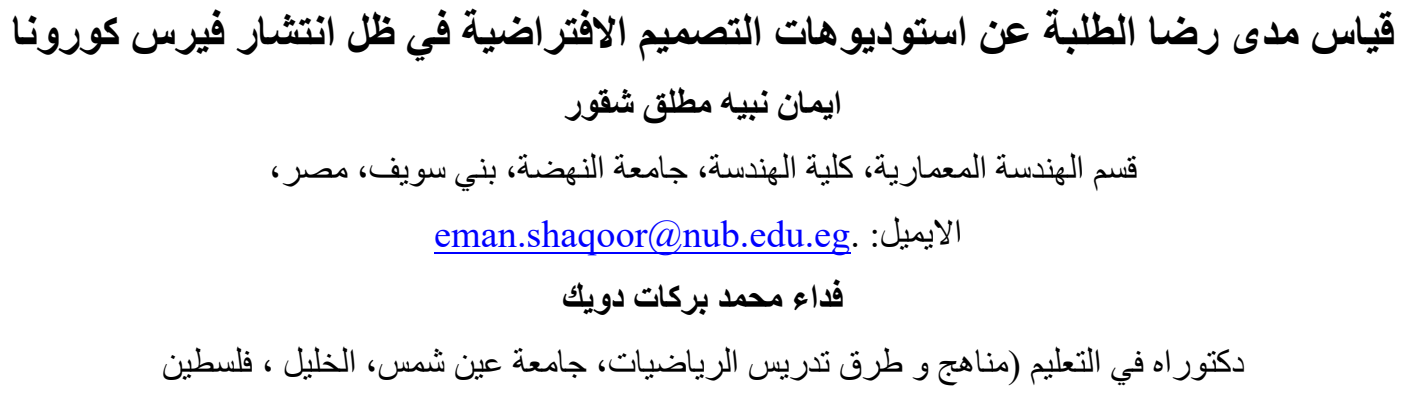

fedadweik@yahoo.com

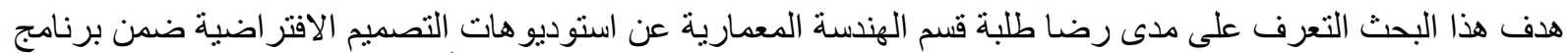

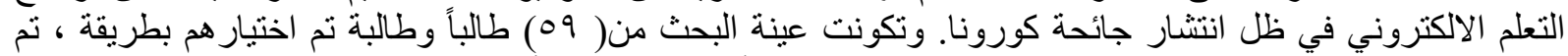

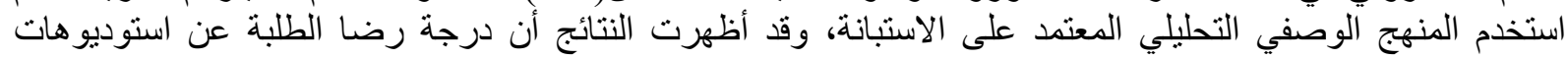




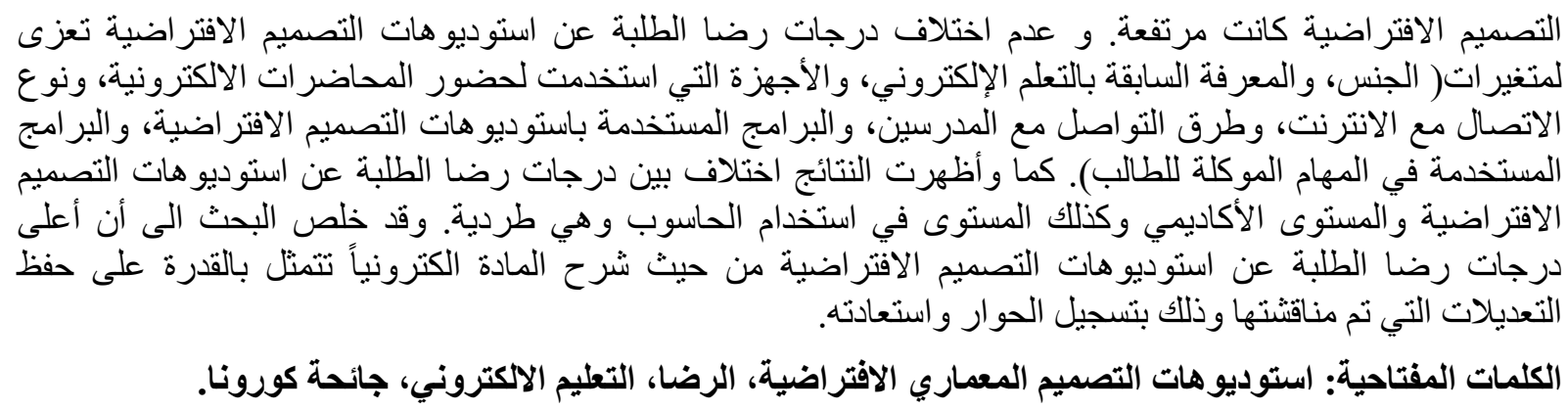

\section{INTRODUCTION}

With the outbreak of the new Corona virus (covid-19) in the world and the declaration of a state of emergency throughout the world, including the Arab Republic of Egypt, and in the context of efforts aimed at overcoming the crisis that may be prolonged due to the high numbers of Corona infections, local educational institutions found themselves facing a great challenge on the level of universities around the world, and due to the importance of the prevention component in defeating the disease, many governments took measures to reduce the human density in the usual gathering places. The education sector was, of course, one of the first sectors to apply this policy, which raised the shares of distance learning in universities, many of which have already begun, under the pressure of exceptional circumstances, to expand the area of benefiting from it, as a temporary alternative to the regular education system until the end of Coronavirus outbreak in order to preserve the health of students and the continuation of the educational process.

Several Arab e-learning initiatives appeared in Egypt and, as well as in other Arab countries, which have tried to overcome this problem [1]. With reference to the beginning of e-learning in university education in Egypt, the beginning was at the end of the seventies of the last century to adopt the idea of distance education, as the National Council for Education and Scientific Research in 1979 proposed an idea to establish an open university. At the beginning of the eighties of the twentieth century Egypt began to apply distance education in the field of university education through the implementation of the qualification program for primary school teachers for the university level.

In the current period, with the interruption of face education and adherence to homes in light of the Corona pandemic, Egyptian educational policies have tended, to adopt many projects that aim to develop and renew the university education system in a way that keeps pace with continuous developments by benefiting from the application of technology that has been successfully developed in the field of education especially university education.

Architectural education is one of the fields of university education, which seeks to use the finest available technologies to access the latest information, data, developments and ideas to solve architectural problems and issues, in addition to their effort to develop and exploit the best capabilities to present ideas and present them in a manner that achieves the goals they seek to achieve. Therefore, it was imperative to go towards e-learning in terms of the ideas it can offer that are solutions to many problems, especially at this time with our suffer from the spread of the Coronavirus [2].

\section{LITERATURE REVIEW}

In general, it can be said that the importance of Measuring the Architecture Faculty students' satisfaction with the virtual design studios in light of the spread of the Corona pandemic seems clear, as it helps students to get a good opportunity to provide them with knowledge, develop their skills and prepare them for a practical work. Among these studies:

What indicated that there is a high speed of the impact of the Corona epidemic on the education system, as the traditional method of education was retreated so the e-learning spread instead because it supports learning from home and thus reduces the interaction of individuals with each other, and reduces the spread of the virus, and that the use of different strategies is important in increasing smoothness, improving education through the Internet [3]. The degree of faculty members' satisfaction with e-learning at King Khalid University was 
(4.04), and the axis of e-learning characteristics (flexibility of time, place and resources) achieved the highest degree of satisfaction, followed by the axis of students' interaction with the content, and the lowest degree of satisfaction with institutional support. Also, differences in the degree of satisfaction with electronic teaching were found due to the academic rank variable between the instructor and an assistant professor in favor of an assistant professor, and there were no significant differences attributable to the variables of gender, specialization, experience, and the type of the electronic course, whether complete or integrated [4].

When studying the modeling of e-learning interaction, learner satisfaction and intentions of continuous learning in Ugandan higher education institutions. The results revealed that the elearning interaction consists of a three-factor structure: the learner interface, the feedback interaction, in addition to the learning content [5]. It was also found that the degree of elearning employment in Kuwait University from the viewpoint of the faculty members at the university was high. It was not clear that there were statistically significant differences in the evaluation of the faculty members to the degree of employing e-learning due to the variable of experience and type of college [6].

Through the of e-learning use in enriching the aesthetic experience of students of the College of Fine Arts, the learner was able, in light of synchronous and asynchronous e-learning, to complete complex digital artworks with accuracy and speed, with the ability to display or print them in varying sizes, with any type of printing, in all stages of the print production, and storing it on any mediator. E-learning allows the presentation of artistic content in the form of texts, static and moving images, graphics, and video clips, as well as computers and smart graphic tools to $\log$ on the Internet and obtain the content of the scientific and technical material to enrich the topic [7]. While students see that the (WebCT) program is useful in learning, as it helps to increase communication between the teacher and the student or the student and his colleagues, in addition to that it facilitated the learning process, especially the possibility of accessing sources of enrichment to the course material through the website, and the greatest benefit for their use for e-learning is that they will master the necessary computer skills [8].

The results of one of the studies indicated a lack of knowledge in the use of e-learning in university learning, the administration's lack of interest in developing teachers' skills to use elearning in their teaching, the lack of an interactive teaching environment full of educational technology resources, and the educational content does not help to use technology in teaching, and weakness electronic research skills of teachers [10]. When describing faculty members' perceptions of using technological applications in teaching at Purdue University in the United States, as a result of their participation in the activities of a professional development project designed to prepare future teachers to use technology. The results showed that teachers' use of technology was significantly higher in their teaching, and that the most common uses in teaching were communicating with students via e-mail, using computerized information sources, implementing students' technology based projects, and assessing students' e-learning, while discussion was through the internet is the least used technological application [10].

Based on the above and through the reviews of previous studies, it can be said that there is a high speed of the Corona epidemic impact on the education system, as the traditional method of education has been retreated so the e-learning spread instead, and that the use of e-learning in university education, as one of the modern methods in the educational process in light of the Corona pandemic, or in general, it lead to enable the learner being, in light of synchronous and asynchronous electronic learning, to complete complex work accurately and quickly, with the ability to display and store it on any mediator. E-learning also allows the presentation of content in the form of texts, static and moving images, graphics, videos, and computers and smart tools allow them to access the internet and obtain the content of scientific material to enrich the topic, and the greatest benefit for their use of e-learning is their mastery of the necessary computer skills. Also, differences in the degree of satisfaction with e-learning were found due to the academic rank variable between the instructor and an assistant professor in favor of an assistant professor, and there were no significant differences attributable to the variables of gender, specialization, experience, college and the type of the electronic course, whether complete or combined. This research came to shed light on the degree of satisfaction of students of the Architecture Faculty about the virtual design studios in light of what we suffer from the spread of the Corona virus and the trend to e-learning. 


\section{INTELLECTION OF THE RESEARCH PROBLEM}

The sense of the research problem stemmed from several things, namely:

1. The current situation that requires universities to use technological applications and the e-learning system as an alternative to the regular learning system as an attempt to continue the educational process, especially after the spread of the new Corona virus and the declaration of emergency.

2. Architectural education singularity and the need for special computer programs to implement its goals, especially in the courses of architectural design, construction, and executive drawings.

3. Through an extrapolation of some studies that stated that the difference of teachers in their own methods is reflected on their teaching strategies; this may confuse students. So it is necessary to go towards the application of this research.

\subsection{RESEARCH PROBLEM}

In the current research problem is determined by answering the following main question: How satisfied are students of the Architecture Faculty with the virtual architectural design studios within the e-learning program in light of the spread of the Corona pandemic, where the material is explained electronically and the ease of displaying the material. The second main question, which states: Are there statistically significant differences at the significance level $(\alpha=0.05)$ between the average degrees of the Architecture Faculty students' satisfaction with the virtual design studios within the e-learning program in light of the spread of the Corona pandemic due to personal and demographic variables (gender, academic level, previous knowledge of e-learning, level of computer use, devices used to attend electronic lectures, type of connection to the internet, methods of communication with teachers, programs used in virtual design studios)? This question will be answered through the following hypothesis: (There are no statistically significant differences at the level of significance $(0.05 \alpha)$.

\subsection{RESEARCH AIMS}

The current research aims at knowing the degree of the Architecture Faculty students' satisfaction with the virtual design studios within the e-learning program in light of the spread of the Corona pandemic. Also revealing the relationship between the degree of the Architecture Faculty students' satisfaction with the virtual design studios within the e-learning program in light of the spread of the Corona pandemic and some variables (gender, academic level, previous knowledge of e-learning, level of computer use, devices used to attend electronic lectures, type of Internet connection, methods of communicating with teachers, programs used in virtual design studios).

\subsection{RESEARCH IMPORTANCE}

The importance of the current research lies in the following:

1. The importance of the topic being researched, as e-learning is the most appropriate solution in light of the exceptional events that the university educational process is going through.

2. It is an objective response to what the lecturers are calling for at the present time regarding the necessity of coping up with modern trends in education, which is the input of an e-learning system in universities and the integration of technology and communication techniques in the practical and theoretical curriculum in the Architecture Department.

3. Shedding light on one of the modern teaching strategies, e-learning in teaching architecture.

4. The current research may be a prelude to new studies and researches dealing with other aspects of electronic architectural learning and distance learning.

5. Enriching scientific research in technical technologies and distance learning in the architecture field. 


\subsection{RESEARCH LIMITS AND TERMS}

Research results are associated with the limit: Students of Architectural Engineering Department at Al-Nahda University in BaniSuief who studied who studied the virtual architectural design studio. The main research terms are:

- E-learning: Transferring educational content to students without adhering to location (campus) restrictions by relying on multiple technical technologies and the Internet to achieve effective and flexible communication between the elements of the learning process.

- Virtual Design Studios: Teaching architectural design through electronic means with a spatial separation between the student and the teacher

\section{RESEARCH PROCEDURES}

\subsection{RESEARCH METHODOLOGY}

In order to achieve the objectives of the research, the researcher used the descriptive and analytical approach in research implementation, as it is the most appropriate approach type suitable for this research. Because it depends on the description of the reality or phenomenon as it exists, its analysis and the statement of the relationship between its components and the opinions that are raised about it, and it is concerned with an accurate description and expresses it qualitatively or quantitatively.

\subsection{RESEARCH COMMUNITY AND SAMPLE}

The research community consisted of all 63 students of the Architecture Department who studied the virtual architectural design studio in Nahda University. The sample (63 students) was chosen by an Intentional method from the research community, where the research tool (the questionnaire) was distributed among 63 of the architecture engineering department's students who Joined a virtual design studio, and 59 questionnaires were retrieved. Thus, the retrieval rate is $94 \%$, which is an acceptable percentage to complete the research. The following Table 1 shows the distribution of the research sample according to the research variables:

Table 1: Characteristics of the demographic sample

\begin{tabular}{|c|c|c|c|}
\hline Variables & Alternatives & Number & $\%$ \\
\hline \multirow[b]{2}{*}{ Gender } & Male & 28 & $47.5 \%$ \\
\hline & Female & 31 & $52.5 \%$ \\
\hline \multirow[t]{4}{*}{ Academic level } & Sophomore & 7 & $\% 11.9$ \\
\hline & Junior & 13 & $\% 22.0$ \\
\hline & Senior 1 & 25 & $\% 42.4$ \\
\hline & Senior 2 & 14 & $\% 23.7$ \\
\hline \multirow{2}{*}{$\begin{array}{l}\text { previous knowledge } \\
\text { of e-learning }\end{array}$} & Yes & 25 & $42.4 \%$ \\
\hline & No & 34 & $57.6 \%$ \\
\hline \multirow{2}{*}{$\begin{array}{l}\text { level of computer } \\
\text { use }\end{array}$} & Advanced & 28 & $47.5 \%$ \\
\hline & Medium or weak & 31 & $52.5 \%$ \\
\hline \multirow{3}{*}{$\begin{array}{l}\text { devices used to } \\
\text { attend electronic } \\
\text { lectures }\end{array}$} & Computer & 16 & $27.1 \%$ \\
\hline & Mobile & 21 & $35.6 \%$ \\
\hline & Many & 22 & $37.3 \%$ \\
\hline \multirow{3}{*}{$\begin{array}{l}\text { type of connection to } \\
\text { the internet }\end{array}$} & wifi & 28 & $47.5 \%$ \\
\hline & mobile data \& wifi & 22 & $37.3 \%$ \\
\hline & mobile data & 9 & $15.3 \%$ \\
\hline \multirow{3}{*}{$\begin{array}{l}\text { methods of } \\
\text { communication with } \\
\text { Professors }\end{array}$} & Conversations via WhatsApp with other applications & 27 & $45.8 \%$ \\
\hline & Voice calling via many apps & 15 & $25.4 \%$ \\
\hline & Via e-mail with other applications & 17 & $28.8 \%$ \\
\hline
\end{tabular}




\subsection{THE RESEARCH TOOL (QUESTIONNAIRE)}

The questionnaire tool was used to study the degree of satisfaction of students of the Architecture Engineering Department with the virtual design studios within the e-learning program in light of the spread of the Covid-19 which consisted of (14) phrases, divided into two parts ((The expected benefit of teaching architectural design studio electronically and the ease of using electronic learning in presenting the material in architectural design). the answer to the paragraphs gradation from the answer (absolutely) to the answer (sometimes) to the answer (always) on the triple scale of (1-3).

\subsection{QUESTIONNAIRE APPLICATION, VALIDITY AND STABILITY}

The validity of the research tool was verified by presenting it to a group of specialized referees, who made some observations and opinions about the validity of the scale in studying the degree of satisfaction of students of the Architecture Engineering Department in NUB with the virtual design studios within the e-learning program in light of the spread of the Covid-19 from the point of view of the Department students, they indicated the validity and suitability of his statements for this purpose.

After the statements of the questionnaire were prepared in their final form, they was entered on the google form, the link was distributed to research sample (students), and the answers were obtained electronically and then the answers were processed statistically and came out with the results and recommendations

The researchers calculated the stability by using the stability of the internal consistency of the respondents' answers to the instrument areas using the stability coefficient of Cronbach alpha on the research community and the results were as follows in Table 2:

Table 2: Stability coefficients

\begin{tabular}{|l|l|l|}
\hline The Field & $\begin{array}{l}\text { Paragraphs' } \\
\text { number }\end{array}$ & $\begin{array}{l}\text { Stability } \\
\text { Coefficient } \boldsymbol{\alpha} \\
\text { Cronbach }\end{array}$ \\
\hline First: the expected benefit of explaining the material electronically & 9 & 0.74 \\
\hline Second: Ease of using electronic learning in presenting the material & 5 & 0.70 \\
\hline Overall degree of satisfaction with expected benefit and ease of use & 14 & 0.82 \\
\hline
\end{tabular}

As is evident from the previous Table, the value of the stability coefficient for the expected benefit of explaining the scientific material electronically was $(0.74)$, the value of the stability coefficient for the expected benefit of explaining the scientific material electronically was (0.70), and the value of the Overall degree of satisfaction with expected benefit and ease of use was (0.82) which indicates that the current research tool is able to reproduce from the current results if re-measuring, researching and using it again under the same conditions, and these values were considered appropriate and acceptable for research purposes and the objectives for which these fields and their expressions have been set.

\subsection{STUDY VARIABLES}

Demographic variables: gender, academic level, previous knowledge of e-learning, level of computer use, devices used to attend electronic lectures, type of Internet connection, methods of communicating with teachers, programs used in virtual design studios

Dependent variables: the total score for the degree of satisfaction of students with the virtual design studios with expected benefit and ease of use. 


\subsection{THE CORRECTION KEY}

After giving the sample members' attitudes numbers that represent significance for their directions from $(1-3)$, the difference of the lowest value was calculated, which is 1 of the highest value, which is $3=2$, which is called the range, then the range value was divided by the number of required fields in judging the results, which is 3 , so that the result $=3 / 2=0.66$, and therefore we continue to increase this value starting from the lowest value in order to give the periods for determining the level and intensity of response depending on the arithmetic mean, and the following Table 3 Shows that:

Table 3: Triple Correction Key

\begin{tabular}{|l|l|}
\hline The arithmetic mean & Level \\
\hline Less than 1.67 & Low \\
\hline From 1.67 to less than 2.33 & Average \\
\hline From 2.33 and more & High \\
\hline
\end{tabular}

\subsection{STATISTICAL PROCESSING}

The necessary data statistical processing was done by extracting numbers, percentages, arithmetic means and standard deviations. The research hypotheses were examined at the level $(\alpha=0.05)$, by means of a t-test for independent samples and a single-variance analysis test, and the Cronbach alpha stability equation was used to examine the stability of the search tool and the coefficients Pearson correlation to check the validity of the search tool, using a computer using the SPSS statistical packages program.

\section{DISCUSSION AND RESULTS}

After completing the preparation and application of the research tools, data were collected, analyzed, and appropriate descriptive statistics were extracted. The following is the answer to the research questions and hypotheses. To answer the main question, which states the following: "What is the degree of the Architecture Engineering Department students' satisfaction with the virtual design studios at NUB within the e-learning program in light of the spread of the Corona pandemic?" The arithmetic averages and standard deviations of the questionnaire statements related to this question were calculated, and the following Table 4 clarifies that.

Table 4: Analysis result for the fields of the study tool related to the degree of students' satisfaction with the virtual design studios

\begin{tabular}{|l|l|l|l|}
\hline The field & $\begin{array}{l}\text { Arithmetic } \\
\text { Averages }\end{array}$ & $\begin{array}{l}\text { Standard } \\
\text { Deviations }\end{array}$ & Level \\
\hline $\begin{array}{l}\text { The expected benefit of explaining the scientific material } \\
\text { electronically }\end{array}$ & 2.36 & 0.39 & High \\
\hline Ease of using electronic learning to display the material & 2.59 & 0.38 & High \\
\hline total score & $\mathbf{2 . 4 4}$ & $\mathbf{0 . 3 6}$ & High \\
\hline
\end{tabular}

It is evident from the previous table that the total score of the research tool areas related to the degree of students' satisfaction with the virtual design studios was high, with the arithmetic average of the total score (2.44) and the total standard deviation of (0.36). It is also evident that the total degree of the expected benefit for explaining the scientific material electronically is high with an arithmetic average (2.36) and the total degree for the ease of using e-learning in the presentation of the material is high with an arithmetic average (2.59). This indicates that e-learning has effectively contributed to achieving educational and learning goals, which work to assist the learner to reach the level of desired knowledge. 
By measuring students' satisfaction in terms of explaining the subject electronically, the arithmetic averages and standard deviations of the expressions of the expected field of interest were calculated to explain the scientific material electronically and arrange them in descending order according to the degrees of the arithmetic average, and the following Table 5 shows that:

Table 5: The results of the analysis related to the expected field of interest to explain the scientific material electronically

\begin{tabular}{|l|l|l|l|l|}
\hline$\#$ & $\begin{array}{l}\text { The degree of students' satisfaction with the virtual } \\
\text { design studios in terms of explaining the material } \\
\text { electronically }\end{array}$ & $\begin{array}{l}\text { Arithmetic } \\
\text { Averages }\end{array}$ & $\begin{array}{l}\text { Standard } \\
\text { Deviations }\end{array}$ & Level \\
\hline 1. & $\begin{array}{l}\text { The ability to save the modifications that have been discussed } \\
\text { by recording the dialogue and restoring it during project } \\
\text { development }\end{array}$ & 2.75 & 0.48 & High \\
\hline 2. & $\begin{array}{l}\text { Benefit from evaluating more than one person in the project } \\
\text { arbitration }\end{array}$ & 2.56 & 0.65 & High \\
\hline 3. & Easy delivery of lectures files, assignments and tests & 2.53 & 0.68 & High \\
\hline 4. & $\begin{array}{l}\text { Designs can be followed easily and maintain focus while } \\
\text { projecting on a computer screen }\end{array}$ & 2.44 & 0.73 & High \\
\hline 5. & $\begin{array}{l}\text { Not to adhere to a limited time for the virtual design studio in } \\
\text { discussing and guiding students }\end{array}$ & 2.34 & 0.73 & Medium \\
\hline 6. & $\begin{array}{l}\text { The quality of the provided materials using e-learning is } \\
\text { appropriate and understandable }\end{array}$ & 2.31 & 0.68 & Medium \\
\hline 7. & $\begin{array}{l}\text { The radical change in the concept of the educational process } \\
\text { from relying on hand tools to relying on electronic tools } \\
\text { affects the level of understanding, discussion and analysis }\end{array}$ & 2.25 & 0.71 & Medium \\
\hline 8. & $\begin{array}{l}\text { Achieving the best outcomes through electronic learning to } \\
\text { students' spare time and divert their focus to study }\end{array}$ & 2.25 & 0.76 & Medium \\
\hline 9. & $\begin{array}{l}\text { The information obtained from the electronic scientific } \\
\text { material is less than what we obtain in the traditional method }\end{array}$ & 2.17 & 0.79 & Medium \\
\hline Total score & $\mathbf{2 . 3 6}$ & $\mathbf{0 . 3 9}$ & High \\
\hline
\end{tabular}

The previous table shows that the total score of the respondents' attitudes towards the degree of the Architecture Faculty students' satisfaction with virtual design studios within the elearning program in terms of explaining the material electronically was high, as the arithmetic average of the total score was (2.36) and the total standard deviation was (0.39). In the forefront of these expressions is the ability to memorize the modifications that were discussed by recording the dialogue and restoring it during the development of the project with an arithmetic average of (2.75) and a standard deviation of (0.48), while the lowest phrase the information obtained from the electronic scientific material less than what we obtain in the traditional method, it has an average of (2.17) and a standard deviation of (0.79). This indicates that e-learning provides a state of stability for the student, which leads to his comfort and relief of boredom and tension.

And to measure students' satisfaction with the ease of using e-learning to present the material, the arithmetic averages and standard deviations of the terms of the field of ease of using elearning in the material presentation were calculated and arranged in descending order according to the degrees of the arithmetic average, and the following Table 6 shows that 
Table 6: The analysis results related to the field of ease of using e-learning to present the material

\begin{tabular}{|c|l|l|l|l|}
\hline$\#$ & $\begin{array}{l}\text { The degree of students' satisfaction with the design studios } \\
\text { in terms of ease of using e-learning to present the material }\end{array}$ & $\begin{array}{l}\text { Arithmetic } \\
\text { Averages }\end{array}$ & $\begin{array}{l}\text { Standard } \\
\text { Deviations }\end{array}$ & Level \\
\hline 1. & $\begin{array}{l}\text { The used software helps to draw, rotate shapes, and make } \\
\text { graphics, zoom and moving. }\end{array}$ & 2.69 & 0.46 & High \\
\hline 2. & $\begin{array}{l}\text { The used programs help to convert design drawings into a Pdf } \\
\text { file and upload it or an image and upload it }\end{array}$ & 2.64 & 0.55 & High \\
\hline 3. & $\begin{array}{l}\text { Flexibility to access the virtual studio from anywhere, using a } \\
\text { computer, tablet or mobile phone }\end{array}$ & 2.58 & 0.56 & High \\
\hline 4. & $\begin{array}{l}\text { Learning platforms help to make edits easily and comments on } \\
\text { designs }\end{array}$ & 2.53 & 0.65 & High \\
\hline 5. & $\begin{array}{l}\text { The used learning platforms help with displaying designs, } \\
\text { tracking and mentoring. }\end{array}$ & 2.51 & 0.60 & High \\
\hline Total score & $\mathbf{2 . 5 9}$ & $\mathbf{0 . 3 8}$ & High \\
\hline
\end{tabular}

It is evident from the previous table that the total score of the respondents' attitudes towards the degree of the Architecture faculty students' satisfaction with the virtual design studios within the e-learning program in terms of ease of using e-learning to present the material was high, as the arithmetic average of the total score was (2.59) and the total standard deviation was $(0.38)$, and it came in the forefront of these phrases: The phrase used programs help to draw shapes, rotate shapes, make drawings, zooming in and moving with an arithmetic average of (2.69) and a standard deviation of (0.46). Whereas the lowest phrase, the phrase the learning platforms used in presenting the designs, follow-up and guidance, help with an arithmetic average of (2.51) and a standard deviation of (0.6). The researcher attributes this result to the students' lack of knowledge of the use of available learning platforms and using them to present designs, which confirms the necessity of introducing students to the advantages of e-learning platforms and how to use them.

From the above, it can be noticed that the degree of the Architecture faculty students' satisfaction with the virtual design studios within the e-learning program in light of the spread of the Corona pandemic was high, and this is confirmed by previous studies that dealt with elearning. To find out that there are statistically significant differences at the level of significance $(\alpha=0.05)$ between the average degrees of Architecture Faculty students' satisfaction with the virtual design studios within the e-learning program in light of the spread of the Corona pandemic due to personal and demographic variables related to (gender, previous knowledge of e-learning, connection type to the Internet, methods of communicating with teachers, the programs used in the virtual design studios). Arithmetic averages, standard deviations and results of independent samples were extracted for the previous variables, as is evident from the following table 7 
Table 7: The testing results to examine the differences in the degree of satisfaction level according to different variables

\begin{tabular}{|c|c|c|c|c|c|c|c|}
\hline \multicolumn{2}{|l|}{ Variables } & \multirow{2}{*}{$\begin{array}{l}\text { Number } \\
28\end{array}$} & \multirow{2}{*}{$\begin{array}{l}\begin{array}{l}\text { Arithmetic } \\
\text { Averages }\end{array} \\
2.44\end{array}$} & \multirow{2}{*}{$\begin{array}{l}\begin{array}{l}\text { Standard } \\
\text { Deviations }\end{array} \\
0.38 \\
\end{array}$} & \multirow{3}{*}{$\begin{array}{l}\begin{array}{l}\text { level of } \\
\text { statistical } \\
\text { significance }\end{array} \\
-0.087\end{array}$} & \multirow{3}{*}{$\begin{array}{l}\text { Freedom } \\
\text { degree }\end{array}$} & \multirow{3}{*}{$\begin{array}{l}\begin{array}{l}\text { Calculated } \\
\text { T value }\end{array} \\
0.931\end{array}$} \\
\hline \multirow{2}{*}{ Gender } & Male & & & & & & \\
\hline & Female & 31 & 2.45 & 0.34 & & & \\
\hline \multirow{2}{*}{$\begin{array}{l}\text { Previous } \\
\text { knowled } \\
\text { ge of e- } \\
\text { learning }\end{array}$} & Yes & 25 & 2.43 & 0.37 & \multirow[b]{2}{*}{-0.160} & \multirow[b]{2}{*}{57} & \multirow[b]{2}{*}{0.873} \\
\hline & No & 34 & 2.45 & 0.36 & & & \\
\hline \multirow{2}{*}{$\begin{array}{l}\text { level of } \\
\text { computer } \\
\text { use }\end{array}$} & Advanced & 28 & 2.52 & 0.37 & \multirow{2}{*}{1.539} & \multirow{2}{*}{57} & \multirow{2}{*}{0.129} \\
\hline & Medium or weak & 31 & 2.38 & 0.35 & & & \\
\hline \multirow{5}{*}{$\begin{array}{l}\text { Academi } \\
\text { c level }\end{array}$} & Sophomore & 7 & 2.28 & 0.40 & & & \\
\hline & Junior & 13 & 2.35 & 0.40 & & & \\
\hline & Senior 1 & 25 & 2.47 & 0.33 & & & \\
\hline & Senior 2 & 14 & 2.58 & 0.34 & & & \\
\hline & Total & 59 & 2.44 & 0.36 & & & \\
\hline \multirow{4}{*}{$\begin{array}{l}\text { Type of } \\
\text { connectio } \\
\mathrm{n} \text { to the } \\
\text { internet }\end{array}$} & wifi & 28 & 2.40 & 0.34 & \multirow{3}{*}{-} & \multirow{3}{*}{-} & \multirow{3}{*}{ - } \\
\hline & $\begin{array}{l}\text { mobile data \& } \\
\text { wifi }\end{array}$ & 22 & 2.54 & 0.35 & & & \\
\hline & mobile data & 9 & 2.36 & 0.41 & & & \\
\hline & Total & 59 & 2.44 & 0.36 & & & \\
\hline \multirow{4}{*}{$\begin{array}{l}\text { Methods } \\
\text { of } \\
\text { communi } \\
\text { cation } \\
\text { with } \\
\text { Professor } \\
\text { s }\end{array}$} & $\begin{array}{l}\text { Conversations via } \\
\text { WhatsApp with } \\
\text { other applications }\end{array}$ & 27 & 2.37 & 0.41 & \multirow{4}{*}{-} & \multirow{4}{*}{ - } & \multirow{4}{*}{ - } \\
\hline & $\begin{array}{l}\text { Voice calling via } \\
\text { many apps }\end{array}$ & 15 & 2.51 & 0.30 & & & \\
\hline & $\begin{array}{l}\text { Via e-mail with } \\
\text { other applications }\end{array}$ & 17 & 2.50 & 0.30 & & & \\
\hline & Total & 59 & 2.44 & 0.36 & & & \\
\hline \multirow{2}{*}{$\begin{array}{l}\text { Programs } \\
\text { used to } \\
\text { attend } \\
\text { electroni } \\
\text { c lectures }\end{array}$} & Microsoft team & 56 & 2.44 & 0.36 & \multirow[b]{2}{*}{-0.515} & \multirow[b]{2}{*}{57} & \multirow[b]{2}{*}{0.609} \\
\hline & Many Programs & 3 & 2.55 & 0.42 & & & \\
\hline
\end{tabular}

From the previous table it is clear to us that there are no statistically significant differences at the level of significance $(\alpha=0.05)$ between the averages of students' satisfaction scores due to variables (gender, previous knowledge of e-learning, type of connection to the Internet, methods of communication with teachers and the programs used in virtual design studios) ( The significance level of the test is greater than 0.05), and this indicates that none of these variables affected the degree of students' satisfaction with the virtual design studios within the e-learning program. The researcher attributes this result to the fact that the methods used, whether in explanation or in communication, are the same for all students

The following table 8 illustrates the extraction of the arithmetic averages and standard deviations, the results of the test results of the single variance analysis of the variable of connection to the Internet, methods of communication with teachers, Academic level and the devices used to attend electronic lectures. 
Table 8: The results of mono- variance analysis according to different variables

\begin{tabular}{|c|c|c|c|c|c|c|}
\hline Variables & $\begin{array}{l}\text { Variance } \\
\text { source }\end{array}$ & $\begin{array}{l}\text { Squares' } \\
\text { total }\end{array}$ & $\begin{array}{l}\text { Freedom } \\
\text { degree }\end{array}$ & $\begin{array}{l}\text { Squares' } \\
\text { average }\end{array}$ & $\begin{array}{l}\text { Calculated } \\
\text { F value }\end{array}$ & $\begin{array}{l}\text { level of } \\
\text { statistical } \\
\text { significance }\end{array}$ \\
\hline \multirow{3}{*}{$\begin{array}{l}\text { Type of } \\
\text { connection to the } \\
\text { internet }\end{array}$} & $\begin{array}{l}\text { Among } \\
\text { groups }\end{array}$ & 0.312 & 2 & 0.156 & 1.222 & 0.302 \\
\hline & $\begin{array}{l}\text { Inside } \\
\text { groups }\end{array}$ & 7.155 & 56 & 0.128 & & \\
\hline & Total & 7.467 & 58 & & & \\
\hline \multirow{3}{*}{$\begin{array}{l}\text { Methods of } \\
\text { communication } \\
\text { with Professors }\end{array}$} & $\begin{array}{l}\text { Among } \\
\text { groups }\end{array}$ & 0.283 & 2 & 0.142 & 1.103 & 0.339 \\
\hline & $\begin{array}{l}\text { Inside } \\
\text { groups }\end{array}$ & 7.184 & 56 & 0.128 & & \\
\hline & Total & 7.467 & 58 & & & \\
\hline \multirow{2}{*}{$\begin{array}{l}\text { Devices used to } \\
\text { attend electronic } \\
\text { lectures }\end{array}$} & $\begin{array}{l}\text { Among } \\
\text { groups }\end{array}$ & 0.447 & 2 & 0.223 & 1.781 & 0.178 \\
\hline & $\begin{array}{l}\text { Inside } \\
\text { groups }\end{array}$ & 7.021 & 56 & 0.125 & & \\
\hline \multirow{3}{*}{ Academic level } & $\begin{array}{l}\text { Among } \\
\text { groups }\end{array}$ & 0.581 & 3 & 0.194 & 1.546 & 0.213 \\
\hline & $\begin{array}{l}\text { Inside } \\
\text { groups }\end{array}$ & 6.886 & 55 & 0.125 & & \\
\hline & Total & 7.467 & 58 & & & \\
\hline
\end{tabular}

To find out the existence of a statistically significant relationship at the significance level $(\alpha=$ 0.05) between the degrees of the Architecture Faculty students' satisfaction with the virtual design studios within the e-learning program in light of the spread of the Corona pandemic and the academic level. The Pearson correlation coefficient test was used among the degrees of Architecture faculty students' satisfaction with the virtual design studios within the elearning program in light of the spread of the Corona pandemic for variables (academic level, and level of computer use) and the following Table 9 shows the results of this test.

Table 9: Spearman correlation coefficient test between student satisfaction degree and academic level

\begin{tabular}{|l|l|l|l|}
\hline \multirow{2}{*}{ Independent variable } & \multicolumn{3}{|l|}{$\begin{array}{l}\text { The dependent variable: the degree of satisfaction of students of the } \\
\text { Architecture department with the virtual design studios }\end{array}$} \\
\cline { 2 - 4 } & Number & $\begin{array}{l}\text { Spearman correlation } \\
\text { coefficient }\end{array}$ & $\begin{array}{l}\text { level of } \\
\text { statistical } \\
\text { significance }\end{array}$ \\
\hline Academic Level & 59 & 0.277 & 0.033 \\
\hline level of computer use & 59 & 0.310 & 0.017 \\
\hline
\end{tabular}

It is noted from the results of the previous table that the value of the correlation coefficient is statistically significant (the degree of statistical significance is less than 0.05), and therefore the previous hypothesis is rejected, and it is concluded that there is a statistically significant relationship between the degrees of Architecture Faculty students' satisfaction with the virtual design studios and the academic level, where the value of the Pearson correlation coefficient is (0.277), as well as the level in computer use, with the value of the Pearson correlation coefficient $(0.310)$, which is positive in both cases, indicating that the higher the academic level and the level of computer use, the greater the students' satisfaction scores with the virtual design studios. This result is clear through the values of the arithmetic average in the 
following table, where it is noticed that the average satisfaction increases with the increase in the academic level and the level of computer use.

\section{CONCLUSIONS}

Through the respondents' opinions, high trends and approval, the above can be summarized by the following conclusions:

1. The total score for the research instrument areas related to students' satisfaction with the virtual design studios was high

2. The degree of students' satisfaction with the virtual design studios in terms of explaining the material electronically is the ability to save the modifications that have been discussed by recording the dialogue and restoring it during the project development, the benefit of evaluating more than one person in the project arbitration, the ease of delivering files for lectures, assignments and tests, designs can be easily followed up and preserved to focus during the presentation on the computer screen, not restricted to limited time for the virtual design studio in discussing and directing students.

3. The degree of students' satisfaction with the virtual design studios in terms of the ease of using electronic learning to present the material is represented by the programs used that help with drawing shapes, making rotation of shapes, making drawings, enlarging and relaying, making manual sketches on sensitive screens using a thermal pen, saving these modifications and sending them to students. The programs used to convert design drawings into a pdf file and upload it or an image and upload it, the flexibility to enter the virtual studio from anywhere and using the computer, tablet or mobile phone, the educational platforms used help make modifications easily and comments on the designs, the learning platforms used to display Designs, monitoring and direction

4. There are no statistically significant differences between the average degrees of Architecture Faculty students' satisfaction with the virtual design studios within the elearning program in light of the spread of the Corona pandemic attributable to the gender variable, previous knowledge of e-learning, the devices used to attend electronic lectures, the type of connection to the Internet, and Communication methods with teachers, and programs used in virtual design studios.

5. There is a statistically significant relationship between students' satisfaction scores with the virtual design studios and the academic level, as well as the level of computer use, which is positive.

\section{RECOMMENDATIONS}

- Investing positive opinions towards using e-learning in teaching design studios and developing plans and programs to benefit from these views

- Paying attention to removing the obstacles that limit the use of e-learning in general, and in teaching design levels in particular, such as the type of devices and photoediting programs.

- Providing training courses and workshops for students to develop their abilities using the e-learning system and its various applications-

\section{REFERENCES}

[1] Alhantouly, T. (2016). The Reality of E-Learning at An-Najah National University and Its Role in Achieving Interaction between Learners from the Viewpoint of Students of the College of Graduate Studies. College of Education programs or members of the faculty. Master Thesis in Educational Administration, An-Najah National University, Nablus, Palestine.

[2] Yulia, H. (2020). Online Learning to Prevent the Spread of Pandemic Corona Virus in Indonesia. ETERNAL (English Teaching Journal), (Vol.11.No.1,pp.48-56)

[3] Afifi, A.(2012). Architectural Education in Palestine, Master Thesis, Faculty of Architecture, An-Najah University, Nablus, Palestine. 
[4] Al Mahya, A. (2020). The Degree of Faculty Members 'Satisfaction with E-Teaching at King Khalid University. Journal of Educational Sciences, (Vol. 12 , No. 1, pp.99150)

[5] Bashir, K. (2019). Modeling E-Learning Interactivity, Learner Satisfaction and Continuance Learning Intention in Ugandan Higher Learning Institutions. International Journal of Education and Development Using Information and Communication Technology, (Vol.15, No.1, pp.21).

[6] Al-Rashidi, A. (2020). The Degree of Employment of E-Learning Kuwait University From The Viewpoint Of The University's Faculty. The Islamic University Journal of Educational and Psychological Studies, (Vol. 28 No.1, Pp. 230-251).

[7] Al-Shammari, W. (2019). Employing Electronic Education in Enriching the Aesthetic Experience of Students of the College Of Fine Arts. Arab Journal of Educational and Psychological Sciences, (Vol. 7, Pp.146-168).

[8] Jonos, G. \& Jonos, B. (2017). A Comparison of Teacher and Student Attitude Concerning Use and Effectiveness of Web- Based Course Management Software. Éducation Technology and Society, (Vol.8, No.2, Pp.125-135).

[9] Kāshmar, L. D. (2017). E-Learning Requirements in the University Educational Process. The Humanities And Social Sciences Generation Journal, (Vol. 28, Pp.149170)

[10] Bai, H. \& Lehman, J. (2015). Impact of a Professional Development Project University Faculty Membres' Perception and Use of Technology. (Electronic version). Journal of social work education, (Vol.35, No. 2, Pp. 234-254 ) 